\title{
Catalytic Degradation of Eriochrome Black T Dye By Fenton and Photo-Fenton Reaction
}

\author{
Nadia A.Youssef1, Seham A. Shaban2, Fatma A.Ibrahim1, Aya S.Mahmoud1 \\ 1. Chemistry department, Faculty of Women Ain Shams University,Helioplis,Cairo,Egypt. \\ 2. Egyptian Petroleum Research Institute (EPRI), Naser City, Cairo,Egypt.
}

\section{Abstract}

The oxidation with Fenton and photo-Fenton reaction in homogeneous system is an effective technology for destruction of a large number of different dyes. The effects of different parameters like the concentrations of $\mathrm{H}_{2} \mathrm{O}_{2}$, the concentration of $\mathrm{FeSO}_{4}$, the initial concentration of the dye and the $\mathrm{pH}$ of the solution on the degradation of eriochrome Black $\mathrm{T}$ (EBT) dye were carried out to investigate the process's optimal operational conditions with the best results at low cost. A suitable operating conditions were selected as: the concentration of $\mathrm{H}_{2} \mathrm{O}_{2} 1.14 \times 10^{-2} \mathrm{M}$, the concentration of $\mathrm{FeSO}_{4} 1.85 \times 10^{-4} \mathrm{M}$, the initial concentration of EBT dye $9.34 \times 10^{-5} \mathrm{M}$ and the $\mathrm{pH}$ equal 3.2 at room temperature. In the given conditions, more than $98.37 \%$ of degradation efficiency was achieved within $60 \mathrm{~min}$. of the reaction. Photo-Fenton reaction was investigated and it was found that the degradation efficiency increased from $94 \%$ by Fenton reaction to $99.83 \%$ by photo-Fenton reaction at $15 \mathrm{~min}$. The kinetic study indicated that the degradation kinetics of EBT dye followed the second-order kinetics.

Keywords: Azo dye; Eriochrome Black T (EBT) dye; Degradation; Fenton and photo-Fenton reaction.

\section{Introduction.}

There are many types of synthetic dyes like azo, vat, nitro, indigo etc. , which are widely used for different industrial processes of various purposes (textile, cosmetics, food, pharmaceutical, paper, pulp manufacturing, dyeing of cloth, leather treatment, printing...). The presence of dyes in water is most undesirable [El Hadad et. al., 2014].

Corresponding author: Aya sabry mahmoud E-mail: yooya626@com. 
Azo dyes, characterized by the presence of one or more azo groups $(\mathrm{N}=\mathrm{N})$ bound to aromatic rings, are the largest and most important class of synthetic organic dyes. It has been estimated that more than $50 \%$ of all dyes in common use are azo dyes because of their chemical stability and versatility [Sun et. al., 2009].

The effluents from these dyes cause an environmental damage to the living organisms by stopping the re-oxygenation capacity of water and also blocking sunlight, thereby, causing a disturbance in the natural growth activity of aquatic life. Furthermore, some of these dyes on passage to drinking water cause damage to human life as some of these dyes are carcinogenic in nature [Ashraf et. al., 2006].

It is, therefore, essential to remove these dyes from water bodies or treat them in such a way so as to minimize the damage to the environment and also decolorize the water.

The oxidation with Fenton reaction based on $\mathrm{FeSO}_{4}$ and $\mathrm{H}_{2} \mathrm{O}_{2}$ is an effective technology for destruction of a large number of the dyes because of their powerful oxidizing capability to oxidize different types of dyes to $\mathrm{CO}_{2}$ and $\mathrm{H}_{2} \mathrm{O}$. The application of Fenton reaction is more attractive for several reasons, $\mathrm{FeSO}_{4}$ is widely available, $\mathrm{H}_{2} \mathrm{O}_{2}$ is easy to handle, safe product and is used as strong oxidant because it can attack most of the organic structures found in the wastewater [Zhu et. al.,2014].

There are several studies related to the use of Fenton and photo-Fenton reaction for the degradation of azo dyes wastewaters [Ramirez et.al.,2005]; [Sun et. al.,2007]; [Gomathi et. al., 2009]. The degradation efficiency of the dye was mainly depended on its chemical characteristics, the generation rate and the concentration of $\mathrm{HO}^{\bullet}$ in the process.

\section{Materials and Method:}

Eriochrome Black T (EBT) dye, $\left(\mathrm{C}_{20} \mathrm{H}_{12} \mathrm{~N}_{3} \mathrm{O}_{7} \mathrm{SNa}\right)$, provided from Aldrich chemical company, Ferrous sulfate $\left(\mathrm{FeSO}_{4} .7 \mathrm{H}_{2} \mathrm{O}\right)$ provided from LOBA Chemic, Hydrogen peroxide (30\% v/v), Hydrochloric acid provided from BIO CHEM. Sodium hydroxide $(\mathrm{NaOH})$, provided from BIO CHEM.

All the chemicals were of analytical grade and were used without further purification. A known dye concentration was prepared in distilled water and used as the stock solution for the studies.

All experiments were carried out at room temperature and the $\mathrm{pH}$ of the solution was adjusted by using hydrochloric acid or sodium hydroxide using a $\mathrm{pH}$ meter (Thermo Scientific Orion 2-Star Benchtop pH Meter Kit, with Refillable Glass pH Electrode). 
The required amount of $\mathrm{FeSO}_{4}$ and $\mathrm{H}_{2} \mathrm{O}_{2}$ were added into the dye solution. Immediately after the addition of $\mathrm{H}_{2} \mathrm{O}_{2}$, the concentrations of the dye were determined spectrophotometrically at the maximum wavelength $\left(\lambda_{\max }\right)$ at $551 \mathrm{~nm}$, at different times in order to study the degradation efficiency of the EBT dye. The operating parameters were adjusted by changing one factor at one time while the other parameters were kept constants.

The spectra of the EBT dye were recorded from wavelength 200 to $800 \mathrm{~nm}$ using a UVVIS spectrophotometer at maximum wavelengths $\left(\lambda_{\max }\right)$ of the dye. The calibration curve for the dye was constructed by plotting the different concentrations of the dye against its absorbance and the value of the regression coefficients $\left(\mathrm{R}^{2}\right)$ was calculated and the unknown concentration of the dye solution can be calculated by using formula $y=S x$. Where, $y$ is the absorbance, $\mathrm{S}$ is the slope and $\mathrm{x}$ is the concentration of the dye.

The degradation efficiency of the dye was calculated by:

$$
\text { Degradation efficiency } \%=\left(1-\frac{C_{d y e, t}}{C_{d y e, 0}}\right) \times 100
$$

Where $\mathrm{C}_{\mathrm{dye}, \mathrm{t}}$ and $\mathrm{C}_{\mathrm{dye}, 0}$ are the concentrations of the dye at $\lambda_{\max }$ at reaction time $\mathrm{t}$ and 0 , respectively.

\section{Results and Discussion.}

\subsection{The effect of the concentrations of $\mathrm{H}_{2} \mathrm{O}_{2}$ on the degradation of EBT dye.}

Hydrogen peroxide plays a very important role as a source of $H O^{\bullet}$ generation in Fenton reaction. The effect of $\mathrm{H}_{2} \mathrm{O}_{2}$ on the degradation of EBT dye was examined by varying initial concentration of $\mathrm{H} 2 \mathrm{O} 2$ from $1.76 \times 10^{-3}$ to $6.62 \times 10^{-2} \mathrm{M}$. This was done when the concentration of $\mathrm{FeSO}_{4}$ was $1.28 \times 10^{-4} \mathrm{M}$, the initial concentration of the dye was $9.34 \times 10^{-5} \mathrm{M}$ and the $\mathrm{pH}$ of the solution was 6.2. The results recorded as shown as in Fig.(1).

From Fig.(1), it was observed that increasing the concentration of $\mathrm{H}_{2} \mathrm{O}_{2}$ from $1.76 \times 10^{-}$

${ }^{3}$ to $1.14 \times 10^{-2} \mathrm{M}$ enhances the degradation of EBT dye at the first $30 \mathrm{~min}$. from $63.32 \%$ to $90.43 \%$, from $72.23 \%$ to $94.85 \%$ at $60 \mathrm{~min}$. and from $89.59 \%$ to $97.50 \%$ at $130 \mathrm{~min}$. of the reaction. This is due to the increasing of $\mathrm{HO}^{\bullet}$ radicals by increasing the concentration of $\mathrm{H}_{2} \mathrm{O}_{2}$.

However, when further increase of the concentration of $\mathrm{H}_{2} \mathrm{O}_{2}$ above $1.14 \times 10^{-2} \mathrm{M}$, the degradation of EBT dye was not improved but dropped down. For example, the degradation efficiencies within $30 \mathrm{~min}$. of the reaction reduced from $90.43 \%$ to $83.71 \%$, from $94.85 \%$ to $89.27 \%$ at $60 \mathrm{~min}$. and decreased from $97.50 \%$ to $93.47 \%$ at $130 \mathrm{~min}$. of the reaction as 
increasing the concentration of $\mathrm{H}_{2} \mathrm{O}_{2}$ from $1.14 \times 10^{-2}$ to $6.62 \times 10^{-2}$ M. [Fentona et. al., 2009]; [Elmorsi et. al., 2010] indicated that the decrease of the degradation efficiency of EBT dye at high concentration of $\mathrm{H}_{2} \mathrm{O}_{2}$ was mainly caused by:

- Consumption of $\mathrm{HO}^{\bullet}$ radicals or production of less reactive radicals (such as $\mathrm{HOO}^{\bullet}$ ) take place by further increasing of $\mathrm{H}_{2} \mathrm{O}_{2}$ concentration due to self-scavenging.

$$
\left(\mathrm{HO}^{\bullet}+\mathrm{H}_{2} \mathrm{O}_{2} \rightarrow \mathrm{HOO}^{\bullet}+\mathrm{H}_{2} \mathrm{O}\right)
$$

- The recombination of $\mathrm{HO}^{\bullet}$ and dimerization to $\mathrm{H}_{2} \mathrm{O}_{2}$.

$$
\left(\mathrm{HO}^{\bullet}+\mathrm{HO}^{\bullet} \rightarrow \mathrm{H}_{2} \mathrm{O}_{2}\right)
$$

- In addition, competitive reactions such as reaction with $\mathrm{HOO}^{\bullet}$ also contributed for the declining of the degradation efficiency of EBT dye.

$$
\left(\mathrm{HO}^{\bullet}+\mathrm{HOO}^{\bullet} \rightarrow \mathrm{O}_{2}+\mathrm{H}_{2} \mathrm{O}\right)
$$

From the results, therefore, it was selected a suitable concentration of $\mathrm{H}_{2} \mathrm{O}_{2} 1.14 \times 10^{-2} \mathrm{M}$.

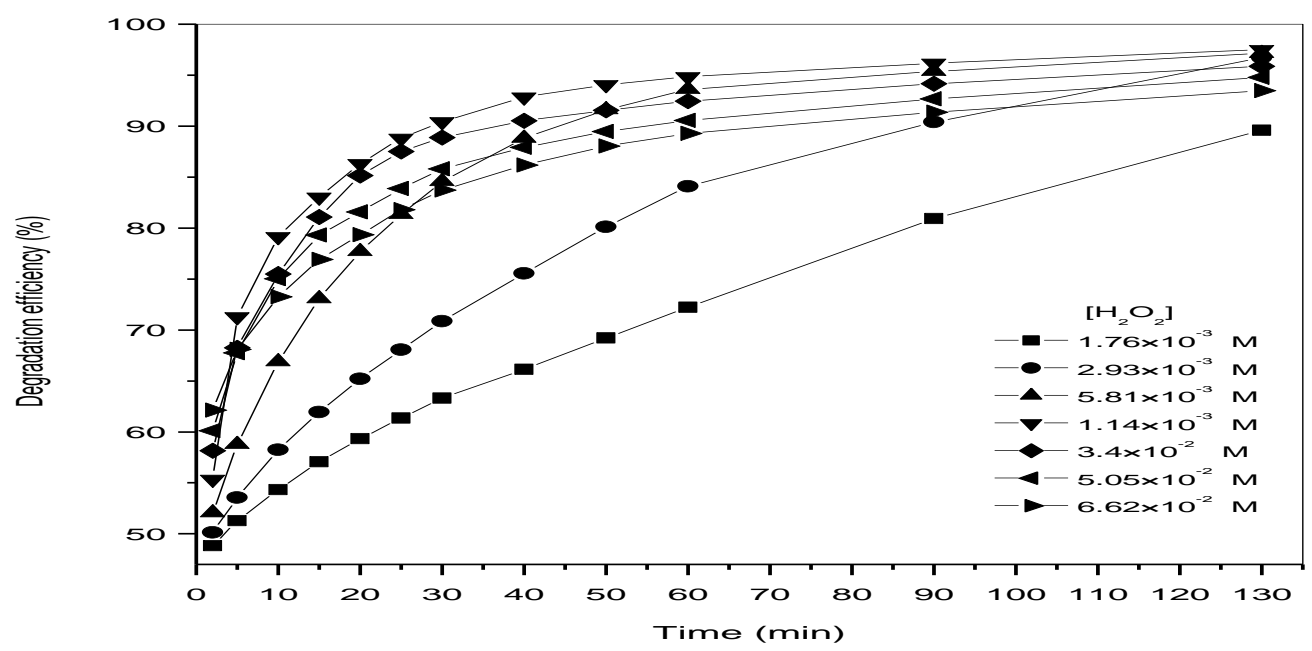

Fig.(1): The effect of the concentrations of $\mathrm{H}_{2} \mathrm{O}_{2}$ on the degradation of EBT dye by Fenton reaction.

\subsection{The effect of the concentrations of $\mathrm{FeSO}_{4}$ on the degradation of EBT dye.}

The effect of the concentrations of $\mathrm{FeSO}_{4}$ is another main parameter in Fenton reaction that catalytically decomposes $\mathrm{H}_{2} \mathrm{O}_{2}$ to generate $\mathrm{HO}^{\bullet}$. The effect of $\mathrm{FeSO}_{4}$ at different concentrations from $3.38 \times 10^{-5}$ to $1.85 \times 10^{-4} \mathrm{M}$, was done at concentration $1.14 \times 10^{-2} \mathrm{M}$ of $\mathrm{H}_{2} \mathrm{O}_{2}$, the initial concentration of the dye was $9.34 \times 10^{-5} \mathrm{M}$ and the $\mathrm{pH}$ of the solution was 6.2 . 
Fig.(2) showed that the degradation efficiency of BET dye was increased with increasing $\mathrm{FeSO}_{4}$ concentration.

At the first $10 \mathrm{~min}$. as the concentration of $\mathrm{FeSO}_{4}$ was increased from $3.38 \times 10^{-5}$ to $1.85 \times 10^{-4} \mathrm{M}$, the degradation efficiencies of EBT dye was increased at first $30 \mathrm{~min}$. from $66.93 \%$ to $93.77 \%$, from $77.83 \%$ to $96.94 \%$ at $60 \mathrm{~min}$. and from $86.86 \%$ to $99.36 \%$ at 130 min. of the reaction. . Hence, it can be concluded that higher $\mathrm{FeSO}_{4}$ concentrations lead to the generation of more $\mathrm{HO}^{\bullet}$ radicals. [Hilal, 2011] indicated that higher $\mathrm{FeSO}_{4}$ concentrations not only make the redox reaction complete but also cause coagulation resulting in improved removal. So that, the concentration $1.85 \times 10^{-4} \mathrm{M}$ of $\mathrm{FeSO}_{4}$ was considered to be suitable concentration for the degradation of EBT dye and above this value the dye will be diluted with $\mathrm{FeSO}_{4}$ solution and the degradation efficiencies couldn't be calculated accurately.

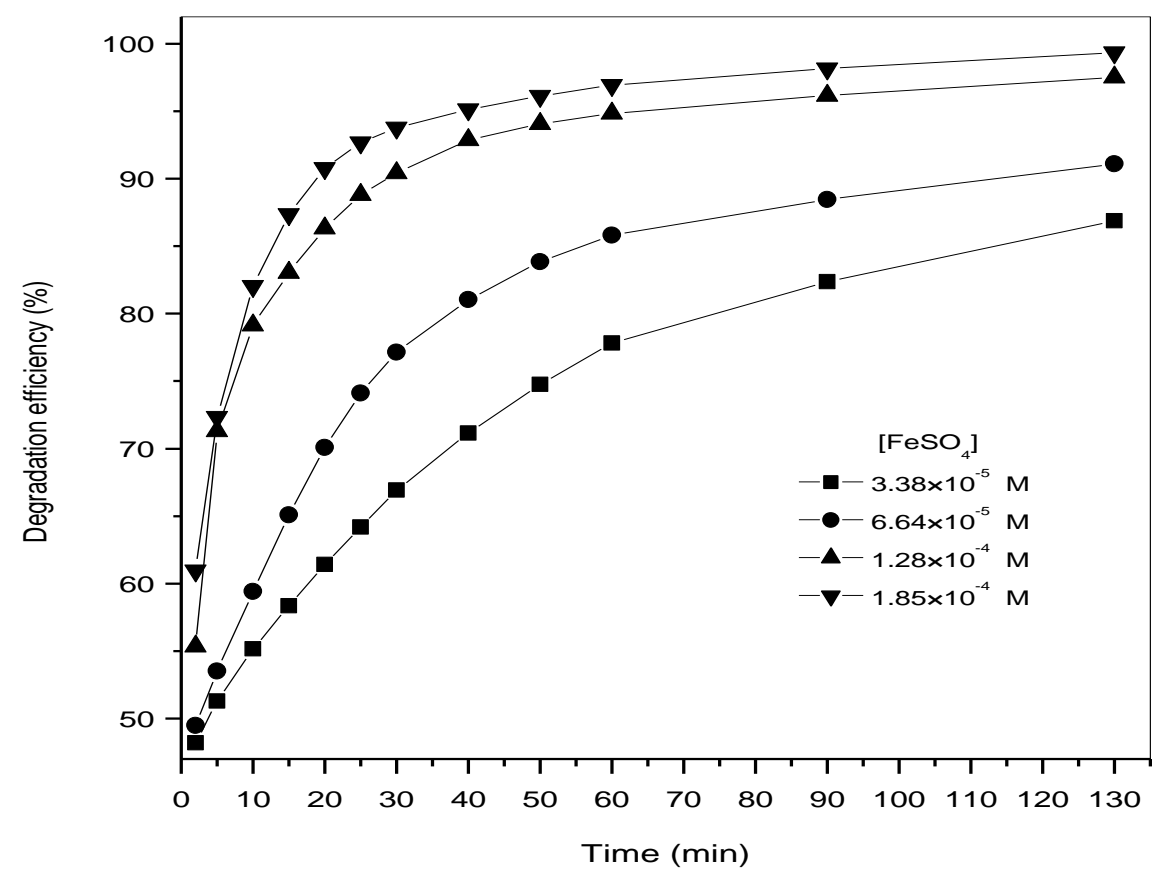

Fig.(2): The effect of the concentrations of $\mathrm{FeSO}_{4}$ on the degradation of EBT dye by Fenton reaction.

\subsection{The effect of the initial concentration of EBT dye on its degradation.}

The effect of variation of the initial dye concentrations on the rate of reaction was also studied by taking different concentrations of EBT dye. The reaction was carried out when the concentration of $\mathrm{H}_{2} \mathrm{O}_{2}$ was $1.14 \times 10^{-2} \mathrm{M}$, the fixed concentration of $\mathrm{FeSO}_{4}$ was $1.85 \times 10^{-4} \mathrm{M}$ and the $\mathrm{pH}$ value of the solution was 6.2. It was found that the degradation efficiency of EBT 
dye increased with increasing the initial dye concentration as shown in Fig.(3). As increasing the concentration of EBT dye from $1.86 \times 10^{-5}$ to $9.34 \times 10^{-5} \mathrm{M}$, the degradation efficiency of EBT dye within $30 \mathrm{~min}$. of the reaction increases from $86.34 \%$ to $93.77 \%$, from $91.52 \%$ to $96.94 \%$ at $60 \mathrm{~min}$. and from $93.76 \%$ to $99.36 \%$ at $130 \mathrm{~min}$. This may be due to the fact that as the concentration of the dye was increased, more dye molecules were available for excitation and energy transfer and hence, an increase in the rate of degradation of the dye was observed [Kapoor and Sharma, 2015]. Also the increase in the concentration of the dye enhances the interaction between the dye and $\mathrm{HO}^{\bullet}$ radical [Ertugay and Acar, 2013].

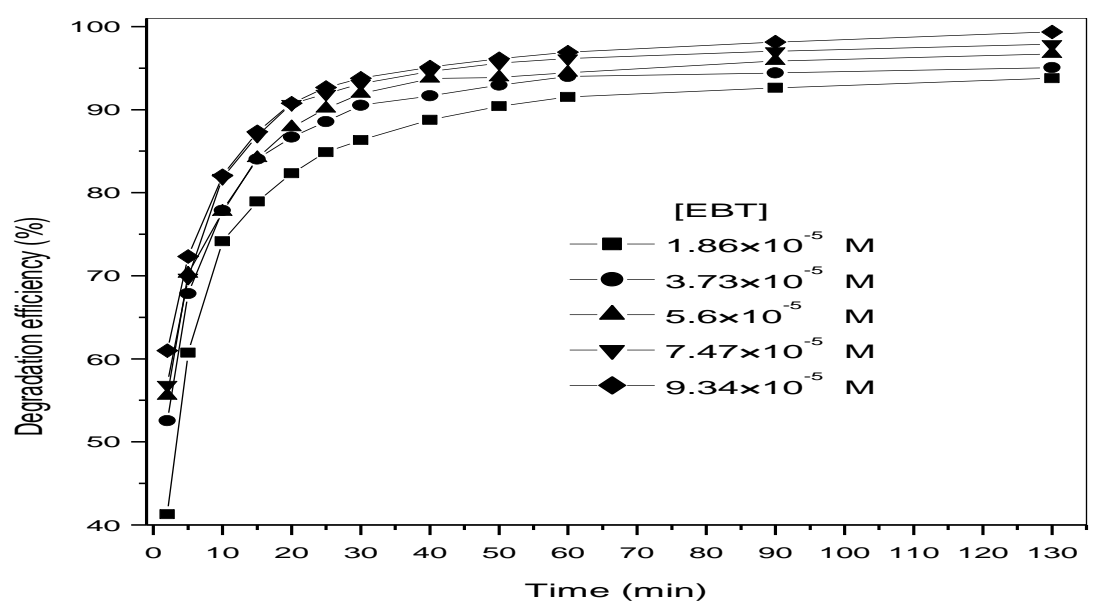

Fig.(3): The effect of the concentration of EBT on its degradation by Fenton reaction.

\subsection{The effect of the initial $\mathrm{pH}$ on the degradation of EBT dye.}

The initial $\mathrm{pH}$ value is a very important parameter in the Fenton reaction because a change in the $\mathrm{pH}$ of the solution, involves a variation of the concentration of $\mathrm{Fe}^{2+}$ ions which is responsible for the production of $\mathrm{HO}^{\bullet}$ radicals. The degradation of EBT dye almost could not be observed at alkaline solutions due to the unstability of $\mathrm{H}_{2} \mathrm{O}_{2}$, and loses its oxidizing potential, and because of the formation of ferrous/ferric hydroxide complexes which lead to the deactivation of ferrous catalyst, and a small amount of $\mathrm{HO}^{\bullet}$ was generated. [Hsueh et. al., 2005]; [Barbusinski and Majewaski, 2003] indicated that the optimal $\mathrm{pH}$ in the range of 2.5-4.0 was reported to be a highly important factor for effective Fenton reaction. Therefore, the $\mathrm{pH}$ of this study focuses on the range of 2.2-6.2 for the degradation efficiency of EBT dye. 
The reaction was carried out for $60 \mathrm{~min}$. by keeping the concentration of $\mathrm{H}_{2} \mathrm{O}_{2}$ was $1.14 \times 10^{-2} \mathrm{M}$, the concentration of $\mathrm{FeSO}_{4}$ was $1.85 \times 10^{-4} \mathrm{M}$ and the initial concentration of EBT dye was $9.34 \times 10^{-5} \mathrm{M}$. When the initial $\mathrm{pH}$ was increased from 2.2 to 3.2 , the degradation efficiency of EBT dye within $30 \mathrm{~min}$. increased significantly from $93.59 \%$ to $96.68 \%$ and increased from $95.85 \%$ to $98.37 \%$ at 60 min. However, the degradation efficiency of EBT dye decreased from $96.68 \%$ to $93.77 \%$ at first $30 \mathrm{~min}$. and form $98.37 \%$ to $96.94 \%$ at $60 \mathrm{~min}$. with further increase of the initial $\mathrm{pH}$ from 3.2 to 6.2 , the results have been depicted in Fig.(4).

This can be accounted to the fact that, at $\mathrm{pH} 3.2$, approximately half of ferrous ions are present in the form of $\mathrm{Fe}^{3+}$ ion and half as complex ions of $[\mathrm{Fe}(\mathrm{OH})]^{2+}$, which are active species. When the $\mathrm{pH}$ was higher than 3.2 , the reaction leads to the decrease in the concentration of this active species and the degradation efficiency was decreased. On the other hand, for $\mathrm{pH}$ below 3.2, the scavenging of $\mathrm{HO}^{\bullet}$ by the excessive of $\mathrm{H}^{+}$. Subsequently, hydrogen peroxide can capture a proton to form an oxonium ion $\mathrm{H}_{3} \mathrm{O}_{2}{ }^{+}$and will make hydrogen peroxide to be electrophilic presumably reducing the reactivity of the reaction between hydrogen peroxide and iron ion. The occurred reactions are described as follows $[\boldsymbol{E} \boldsymbol{L}$

Hadad et .al., 2014]:

$$
\begin{gathered}
\mathrm{HO}^{\bullet}+\mathrm{H}^{+}+\mathrm{le}^{-} \rightarrow \mathrm{H}_{2} \mathrm{O} \\
\mathrm{H}_{2} \mathrm{O}_{2}+\mathrm{H}^{+} \rightarrow \mathrm{H}_{3} \mathrm{O}_{2}^{+}
\end{gathered}
$$

Inhibition of $\mathrm{HO}^{\bullet}$ formation at $\mathrm{pH}$ below 3.2 is due to the decrease of the soluble amount of $\mathrm{Fe}^{3+}$ responsible for the continuity of the oxidation process that is in equilibrium with other iron species $\mathrm{Fe}(\mathrm{OH})_{2}{ }^{+}$and $\mathrm{Fe}(\mathrm{OH})^{2+}$ as follows:

$$
\mathrm{H}_{2} \mathrm{O}_{2}+\mathrm{Fe}^{3+} \rightarrow \mathrm{Fe}^{2+}+\mathrm{H}^{+}+\mathrm{HO}^{\bullet}
$$

Therefore, it was selected 3.2 as a suitable initial $\mathrm{pH}$ value. 


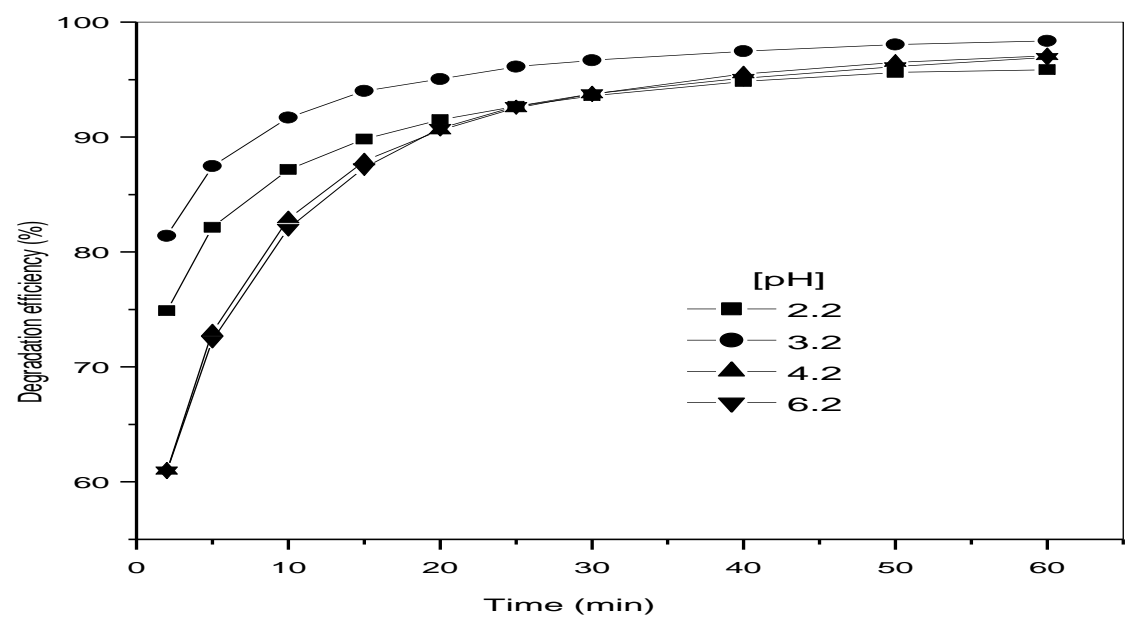

Fig. (4): The effect of the initial pH on the degradation of EBT dye by Fenton reaction.

\subsection{The effect of photo-Fenton reaction on the degradation of EBT dye.}

The generation of hydroxyl radicals from $\mathrm{H}_{2} \mathrm{O}_{2}$ in the presence of $\mathrm{FeSO}_{4}$ have been shown to be enhanced by light [Neatmtu et. al., 2003]. The comparison between Fenton and photo-Fenton reaction are shown in Fig.(5). It was found that the degradation efficiency increased at the first $2 \mathrm{~min}$ from $81.40 \%$ by Fenton reaction to $91.61 \%$ by photo-Fenton reaction and increased from $94 \%$ by Fenton reaction to $99.83 \%$ by photo-Fenton reaction at $15 \mathrm{~min}$. It was found that the reaction was completed and the degradation efficiency of EBT dye was reached to the maximum value at $15 \mathrm{~min}$. by photo-Fenton reaction. The reaction was carried out by keeping the concentration of $\mathrm{H}_{2} \mathrm{O}_{2}$ was $1.14 \times 10^{-2} \mathrm{M}$, the concentration of $\mathrm{FeSO}_{4}$ was $1.85 \times 10^{-4} \mathrm{M}$, the initial concentration of EBT dye was $9.34 \times 10^{-5} \mathrm{M}$ and $\mathrm{pH}$ was 3.2.

The rate of Fenton reaction was strongly increased by irradiation with UV/visible light [Arslan and Balcioglu, 2011]. During the reaction, $\mathrm{Fe}^{+3}$ ions are accumulated in the system and after $\mathrm{Fe}^{+2}$ ions are consumed, the reaction practically stops. Photochemical regeneration of ferrous ions $\mathrm{Fe}^{+2}$ by photo reduction of ferric ions $\mathrm{Fe}^{+3}$ is the proposed mechanism. The new generated ferrous ions react with $\mathrm{H}_{2} \mathrm{O}_{2}$ generating a second $\mathrm{HO}^{\bullet}$ radicals and ferric ions, and the cycle continues [Verma et.al., 2012].

In the presence of light: $\quad \mathrm{Fe}^{+3}+\mathrm{H}_{2} \mathrm{O}_{2} \rightarrow \mathrm{Fe}^{+2}+\mathrm{HO}^{\bullet}$ 


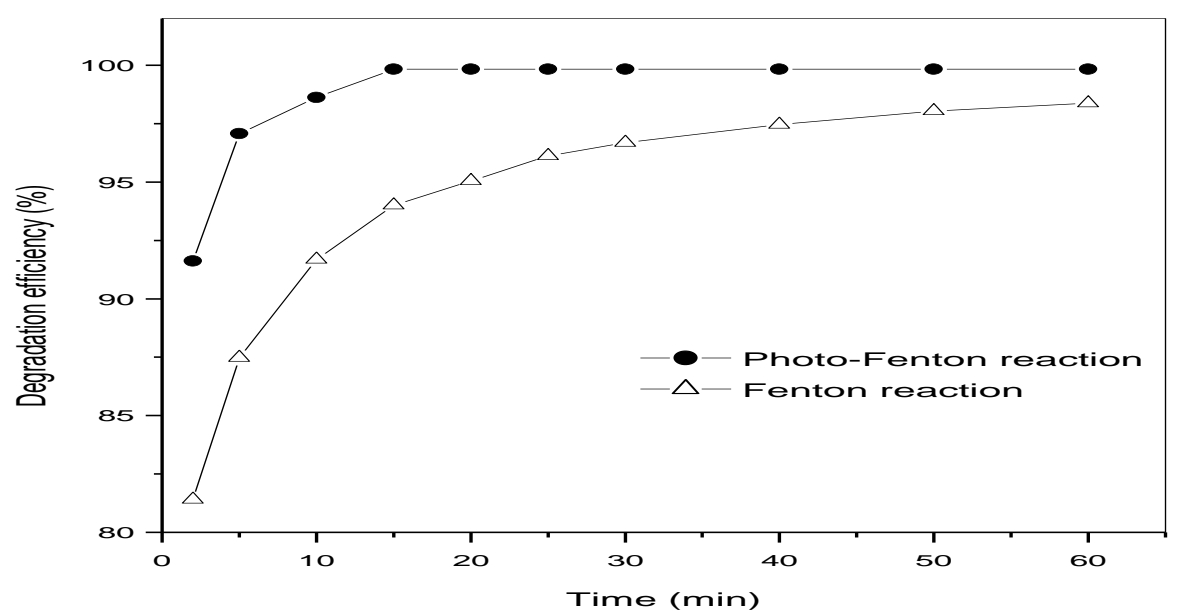

Fig. (5): The degradation efficiency of EBT dye by Fenton and photo-Fenton reaction.

\subsection{Kinetic study for the degradation of EBT dye.}

The degradation kinetics of EBT dye by Fenton and photo-Fenton reaction were studied at zero-, first- and second-order reaction kinetics

Regression analysis based on the zero-, first- and second-order reaction kinetics for the degradation of EBT dye by Fenton and photo-Fenton reactions were conducted and the results were shown in Fig. (6) Comparing the regression coefficients $\left(\mathrm{R}^{2}\right)$ obtained from Fig.6.(A),(B) and (C), it can be seen that $\mathrm{R}^{2}$ based on the second-order reaction kinetics (Fig.6(C)) was 0.99858 and 0.7659 for Fenton and photo-Fenton reaction respectively, which was obviously much better than that based on the zero-order and the first-order reaction kinetics. The results indicated that the degradation kinetics of EBT dye followed the secondorder kinetics well. 

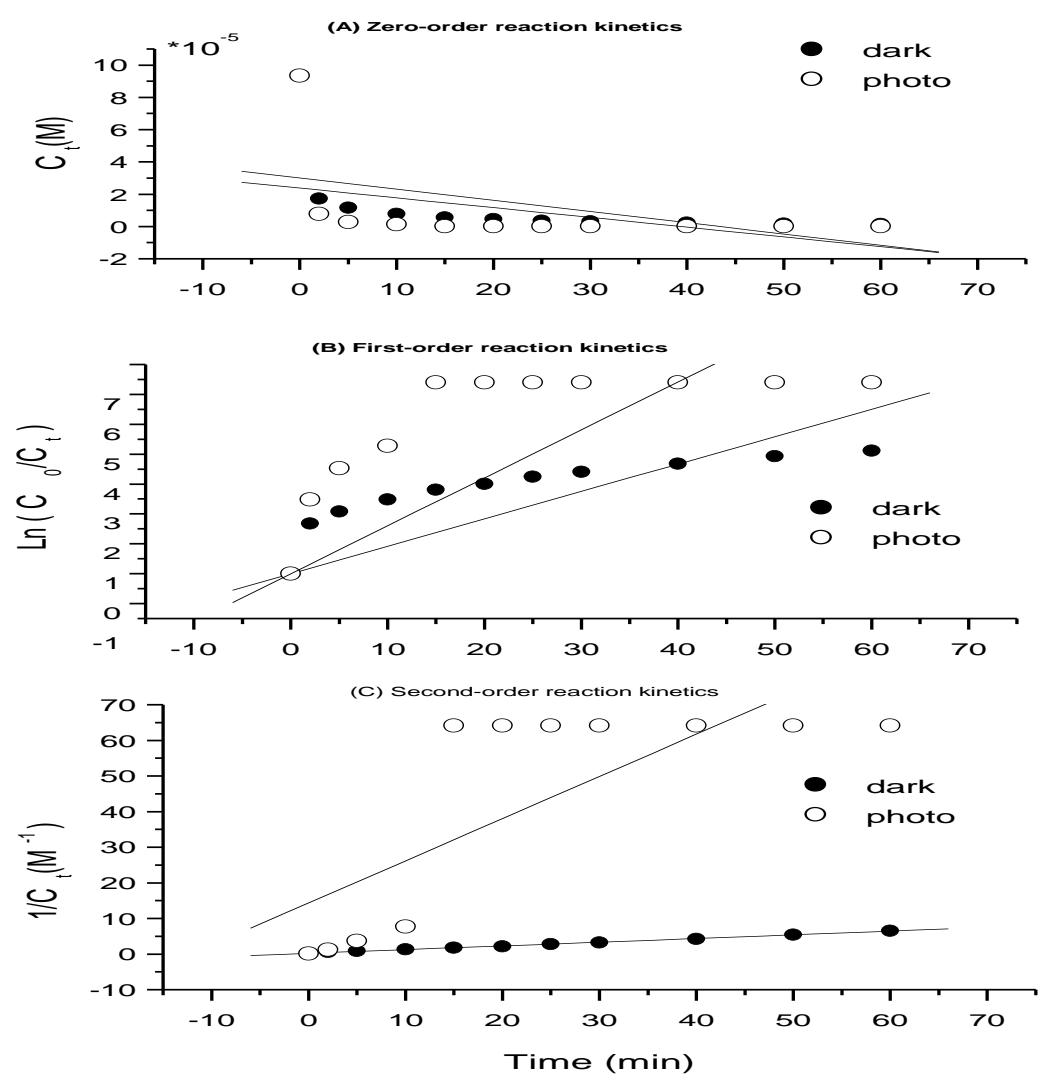

Fig. (6 ): The degradation of EBT dye by Fenton and photo-Fenton reaction.

(A) Zero-, (B) first-, (C) second-order reaction kinetics.

The apparent kinetic rate constants, $k_{2}$, of the degradation of EBT dye was found to be $0.10389 \times 10^{5}$ and $1.18444 \times 10^{5} \mathrm{M}^{-1} \mathrm{~min}^{-1}$ by Fenton and photo-Fenton reaction respectively at an optimal initial concentration of EBT dye was $9.34 \times 10^{-5} \mathrm{M}$, the concentration of $\mathrm{H}_{2} \mathrm{O}_{2}$ was $1.14 \times 10^{-2} \mathrm{M}$, the concentration of $\mathrm{FeSO}_{4}$ was $1.85 \times 10^{-4} \mathrm{M}$ and the $\mathrm{pH}$ equal 3.2 at room temperature.

\section{Conclusions.}

In this work, the degradation of EBT dye in aqueous solution by Fenton reaction has been studied at different experimental conditions, including, the effect of different parameters like the concentrations of $\mathrm{H}_{2} \mathrm{O}_{2}$, the concentration of $\mathrm{FeSO}_{4}$, the initial concentration of the dye and the $\mathrm{pH}$ of the solution were investigated. A suitable operating condition were selected as: the initial concentration of EBT dye was $9.34 \times 10^{-5} \mathrm{M}$, the concentration of $\mathrm{H}_{2} \mathrm{O}_{2}$ was $1.14 \times 10^{-2} \mathrm{M}$, the concentration of $\mathrm{FeSO}_{4}$ was $1.85 \times 10^{-4} \mathrm{M}$ and the $\mathrm{pH}$ was 3.2 at room 
temperature. In the given conditions, more than $98.37 \%$ of degradation efficiency was achieved within $60 \mathrm{~min}$. of reaction

Photo-Fenton reaction was investigated and it was found that the degradation efficiency increased at the first $2 \mathrm{~min}$ from $81.40 \%$ by Fenton reaction to $91.61 \%$ by photoFenton reaction and increased from $94 \%$ by Fenton reaction to $99.83 \%$ by photo-Fenton reaction at $15 \mathrm{~min}$. It was found that the reaction was completed and the degradation efficiency was reached to the maximum value at $15 \mathrm{~min}$. by photo-Fenton reaction.

The kinetic study indicated that the degradation kinetics of EBT dye followed the second-order kinetics.

\section{References.}

Arslan., And Balcioglu I.A, Degradation of commercial reactive dyestuffs by heterogeneous and homogeneous advanced oxidation processes, Environmental Technology,22-7, 813-822 (2011).

Ashraf S. S., Rauf M.A., Alhadrami S., Degradation of Methyl Red using Fenton's reagent and the effect of various salts, Dyes and Pigments 69 ,74-78 (2006).

Barbusiński1 K. and Majewski J., Discoloration of Azo Dye Acid Red 18 by Fenton Reagent in the Presence of Iron Powder, Polish Journal of Environmental Studies,12, 2, 151-155 (2003).

El Haddad M., Regti A., Laamari M., Mamouni R., Saffaj N., Use of Fenton reagent as advanced oxidative process for removing textile dyes from aqueous solutions, J. Mater. Environ. Sci. 5 (3),667-674 (2014).

Elmorsi T.M., Riyad Y.M., Mahmoud Z.H., Abd El Bary H.M., Decolorization of Mordant red 73 azo dye in water using $\mathrm{H}_{2} \mathrm{O}_{2} / \mathrm{UV}$ and photo-Fenton treatment. Journal of Hazardous Materials 174, 352-358 (2010).

Ertugay N.and Acar F. N. ,Removal of COD and color from Direct Blue 71 azo dye wastewater by Fenton's oxidation: Kinetic study, Arabian Journal of Chemistry, (2013).

Fentona R., Dotycz K. and Chemizmu C., Fenton Reaction - Controversy Concerning The Chemistry, Ecological Chemistry and Engineerings. 16 (3), 347-358 (2009).

Gomathi D. L., Girish K. S., K. Mohan R., Photo fenton like process $\mathrm{Fe}^{3+} /(\mathrm{NH} 4)_{2} \mathrm{~S}_{2} \mathrm{O}_{8} / \mathrm{UV}$ for the degradation of Di azo dye congo red using low iron concentration, Central European Journal of Chemistry, Central European Journal of Chemistry, 7(3), 468-477 (2009).

Hilal N.M.,Treatment of Reactive Dyeing Wastewater by Different Advanced Oxidation Processes Der Chemica Sinica, 2 (4), 262-273 (2011).

Hsueh C.L., Huang Y.H., Wang C.C., Chen C.Y., Degradation of azo dyes using low iron concentration of Fenton and Fenton-like system, Chemosphere ,58, 1409-1414 (2005). 
Kapoor I. and Sharma S., Degradation of Congo red Using Fe-Loaded Montmorillonite Clay as a Heterogeneous Photo-Fenton Catalyst, JCBPS,1 5142-151,(2015).

Neamtua M., Yediler A., Siminiceanu I. and Kettrup A., Oxidation of commercial reactive azo dye aqueous solutions by the photo-Fenton and Fenton-like processes Journal of Photochemistry and Photobiology A: Chemistry 161, 87-93 (2003).'

Ramirez J.H., Costa C.A., Madeira L.M., Experimental design to optimize the degradation of the synthetic dye Orange II using Fenton's reagent, Catal. Today107-108, 68-76 (2005).

Sun J.H., Sun S.P., Wang G.L., Qiao L.P., Degradation of azo dye Amido black10B in aqueous solution by Fenton oxidation process, Dyes Pigments 74 647-652(2007).

Sun S.P., Li C.J., Sun J.H., Shi S.H. and Fan M.H.,Decolorization of an azo dye Orange G in aqueous solution by Fenton oxidation process: Effect of system parameters and kinetic study, Journal of Hazardous Materials .161 , 1052-1057 (2009).

Verma A., Amarpreet K., and Manisha V., Degradation and decolourization of reactive black 5 dye using sono photo Fenton, Environment Sciences and Technology,4, 37 (2012) .

Zhu G.C, Shou J. X., Qian J.W., Xin $\underline{\text { H. Z. }}$, Qiu M.Q., Degradation of Methylene Blue by Fenton-Like Reaction, J. Advanced Materials Research, 1065 - 1069, 3127-3130 (2014). 
الملخص العربى

التكسير الحفزي لصبغة الايرو كروم بلاك تي بواسطة تفاعل الفتتون والفوتوفنتون

نادية عبد الحكيم يوسف' ، سهام شعبان' ، فاطمة عبد السميع ابراهيم' ، آية صبري محمود'

$$
\text { 1 . .قعم الكيمياء ،كليه البنات ــامعة عين شمس. }
$$

هنالك انواع عديدة من الصبغات تستخدم في مجالات صناعية متعددة ولكنها تعتبر من اكثر المواد

الملوثه للبيئة و التي تسبب امر اض عديدة للانسان لذلك لابد من التخلص منها بطرق آمنة ، ومن أفضل الطرق طريقه التكسير الحفزي بواسطة تفاعل الفنتون والفوتوفنتون .

قد تمت در اسة تاثيرتفاعل الفنتون والفوتوفنتون على التكسير الحفزي لصبغة الايروكروم بلاك تي من خلال التغير في تركيز فوق اكسيد الهيدروجين ، التغير في تركيز كبريتات الحديدوز، التغير في تركيز ات صبغة الايروكروم بلاك تي بالأضافه لدر اسة التغير في تاثير الاس الهيدروجيني للصبغة. وقد تم التوصل الى ان افضل تركيزات هي : نركيز فوق اكسيد الهيدروجين 10 × 14 × 14 مولر، كبريتات الحديدوز 40 × 1.85مولر، تركيز الصبغة 5010×9.34 مولر، و الاس الهيدرجيني للصبغة 3.2 في درجة حرارة الغرفة.

وقد تم الحصول على نسبه تكسير للصبغة 94\% بو اسطه تفاعل الفنتون وزادت كفائة التكسير الى 99.83\% بو اسطه تفاعل الفوثو فنتون .

وتمت دراسة الكيمياء الحركية للتفاعل بواسطة الفنتون والفوتو فنتون وتم الوصول الى ان

التفاعل يسلك الرتبة الثانية من الكيمياءالحركية لتكسير صبغة الايروكروم بلاك تي . 